Article

\title{
On the Question at the End of Theodicy
}

\author{
Anthony B. Pinn
}

Department of Religion, University of Rice, Houston, TX 77005-1892, USA; pinn@rice.edu

Received: 8 November 2017; Accepted: 1 December 2017; Published: 8 December 2017

Abstract: This article argues that theodicy provides an insufficient response to suffering - one that often further victimizes those who suffering most. In it's place, I argue for a moralist response based on Albert Camus and W. E. B. Du Bois.

Keywords: suffering; black lives matter; theodicy; race; racial disregard

What did I do to be so black and blue.

-Fats Waller

\section{The Question: Theodicy and Racial Disregard}

For the theistically inclined, the final court of appeal tends to be theodical in tone and content, the Job-like speaking to the "wind" ${ }^{\prime}$. Yet, there is a difference in the two narratives: Job questions and receives an angry and dismissive response that renders suffering a mystery to humans and a riddle understandable only by God, who keeps answers to God's self. On the other hand, the racially despised are met with more pain and deafening silence that means to crush. For Job, it was the loss of all that mattered (family, friends, dignity, agency, bodily integrity, and so on) due to a wager between God and other forces, and for the race-discarded, it is the irrational impact of non-biological markers on their movement through a death dealing society. ${ }^{2}$ Nonetheless, despite obvious differences between Job and the racially disregarded, they share something related to the nature of suffering: social circumstances matter, and the graphic nature of this situation becomes more visible over time.

This is not to say current patterns of disregard point out new arrangements of life. Rather, they intensify and make more difficult dismissal of the destructive nature of the social codes directing collective life. Existential circumstances threaten the delicate sense of meaning and purpose that propel the human animal. It is a delicate balance indeed, and one grounded often in metaphysical assumptions and goals. For the religiously inclined, theological argumentations and hope(s) of a transcending variety provide a filler or glue between the gaps in life narratives.

What I point to is not simply the socio-political and economic disregard that makes life less than ideal based on color and its connotations. Although such connotations are death dealing in their own way, what I intend to highlight is a more elemental nudging toward meaninglessness that undergirds these more readily present challenges. Those challenges attack one's right to occupy physical time and space, and the underlying angst is produced by a deeper troubling not of occupation of time and space but to the significance of the human animal in that time and space.

This dilemma of rightful being in time and space promotes a particularly tenacious modality of anxiety tied to a sense that the pain and misery such circumstances entail has gone unnoticed, met with indifference. This situation often prompts a desire to prove worthiness through demonstrations of

1 I would like to thank the reviewer who provided such valuable feedback on my essay. I have worked to provide attention to the insights and questions posed in that review, and I believe doing so has made this a better article.

2 The Book of Job points to the questionable character of God-i.e., pride that sets up humans as pawns for play. I further interrogate the character of God in relationship to the story of Nimrod. See (Pinn and Callahan 2007). 
spiritual and moral fitness. Standards of an assumed cosmic variety are difficult to meet, but even this failure when acknowledged and owned provides small comfort within a realm of suffering as those longing for righteousness await divine assistance. Or, as so many Christians are known to rehearse: "More like Jesus let me be ..."

The asceticism, strength of soul, purity, and charity outlined and graphically illustrated in the African American collective context has often been the stuff of social existence. Of course, there are examples of African Americans-many in the 19th century-who embraced extreme markers of righteousness and perhaps some of this bleeds into more contemporary modalities of Pentecostalism, for example. But as a mainstay, these have presented themselves as religiously enacted elements of life premised on socio-economic and political need, resolved through a turn to the material world pushed to give more, to surrender more space. (That, surely, is a take away from black and womanist theologies.) The "what is to be made of me" is replaced by a "what is to be made of us?" In this context, the application of human standards involves attention to the construction of blackness, and what Cornel West, has called a genealogy of racism that allows the humanity of blacks as a contemporary-but troubled—recognition (West 1982). It, this narration of race prompting questions of "becoming", finds particular modes of saintliness wanting and tends to categorize much of this existential distancing as otherworldly confusion. In a word, such efforts are sustained not because they prove fruitful, but precisely because they do not—a failure that is absorbed and re/presented as a personal shortcoming that can, or should, be overcome through continued effort. It is, for example, a failure of will. ${ }^{3}$

Within religious quarters, the more fundamental nature of racial violence has prompted a range of theological and philosophical questions concerning the nature of embodied life-particularly related discourses of moral evil produced and encountered within the realm of human interactions. This is the realm of theodicy: what can be said about God in light of human suffering in the world? Despite common assumptions, theodicy does not always encourage an otherworldly orientation. Rather, my argument is theodical efforts have no choice but to promote redemptive suffering orientation within a historical framework. ${ }^{4}$

God is perceived as present in human history and concerned with the "good," and humans are real subjects of history whose existence is marked by injustice and misery. Furthermore, this misery and injustice are real—not an idea, not an illusion, but issues with material and historical consequences. These consequences are death dealing at worse and metaphysically deforming at best. Some type of resolution is necessary, one that acknowledges felt presence of all three-God, humanity, suffering. Herein lies the problem for some theists: if all three are real, and God is defined by at least a portion of what believers say about God, then God has some ability to act in the world. ${ }^{5}$ God acting in the world would mean God is aware of injustice/misery and therefore must be "ok" with ongoing conditions. If God is "ok" with the condition of humans, and God is at least remotely good, then misery must have a cosmic rationale. Unless believers are willing to say God (1) endorses evil or (2) does not exist, there must be some merit (at least indirectly) in suffering. ${ }^{6}$

This is the wager suggested by the above: religion must encourage believers to surrender something. They must surrender certain modalities of experience, certain ways of knowing, and grant authority to an unproven but assumed to be concerned God. That is to say, they must find some

\footnotetext{
I more fully develop this in (Pinn 2017).

I make this argument in full: (Pinn 1995).

I acknowledge, however, that some theists embrace a self-limiting God. However, this begs the question: What value does God see in suffering that God would limit God's self in order to allow it? This lends itself to redemptive suffering.

6 The percentage of African Americans who hold to no notion of God would suggest some (and a growing number of "some") have moved in the direction of option two. Still, so many continue to believe and address the dilemma by saying that suffering might be deserved punishing. Some of the extreme examples of this include the assumption of many that natural disasters (e.g., Hurricane Katrina) are the result of sin. Others argue that God takes this situation and uses it pedagogically: we learn something from it. Theological wrestling with race-based misery is full of both examples-from the early years of the country pushing into the present.
} 
type of merit in suffering. Mindful of this, theodicy can be addressed as truncating of a particular metaphysical substance (e.g., human integrity and agency) in that it seeks to find in some form a positive outlook on suffering. From my vantage point, to call suffering "redemptive" or to claim it has some merit is a challenge to the integrity of human life.

Through a looking "beyond" for the cause of disregard, for example, the human is reduced: the significance of human activity (e.g., movement in the world meant to maintain the integrity and dignity of life) is consumed through an appeal to cosmic determinations. As one might imagine, this requirement to surrender something disproportionately impacts those who have already faced violence. This is precisely my point: theistic effort to "save" God puts those who suffer most at greater risk. My statement is not an endorsement of this approach; it is a critique of theological responses to suffering that create greater disregard for those who already suffer disproportionately.

After all this, theodicy generates no answers that do not further beg the question or further challenge the integrity of those most prone to socially induced suffering. One might name this predicament theological absurdity-something akin to Albert Camus's philosophical absurdity, and both modes of absurdity pull at our existential arrangements and challenge our socialization regarding narratives of possible "Unity" and coherence of a deeply meaningful kind-e.g., metaphysical certainty concerning the meaning and outcome of life. ${ }^{7}$ To the extent it can be argued that theodicy provides an answer to suffering, it does so at great risk to those who suffer most.

In the rest of this essay, I give consideration to the above problem of struggle-death viewed through a moralist discourse anchored by the likes of Camus and W. E. B. Du Bois, and I do so in light of recent US social developments. ${ }^{8}$

\section{Social Circumstances and Black Lives: Pretext for a Question ${ }^{9}$}

The situation cannot be overstated: we live a legacy of racial violence meant to confine and manage. The manner in which the US orchestrates this process of control has entailed the destruction of difference by brutalizing raced bodies whenever they are "out of place" or out of "time". ${ }^{10}$ The terror involved in this process isn't simply the threat of death, but the inability to anticipate what will trigger violent response to blackness. As with Philando Castile in Minnesota-the land of "nice-ness" - compliance can be deadly. Any sign of struggle—even for one's breath—can be understood as a threat to the safety of law enforcement and, as was the case for Eric Garner, can result in death. The jail cell as a place of confinement can also be a death chamber, as Sandra Bland's demise makes clear. ${ }^{11}$ There are no decipherable ground rules for survival if one happens to live in black flesh. Those black men and women who have been murdered by police officers died simply because they occupied time and space in a way considered threatening. They were in the wrong place, or they demanded respect and the exercise of their agency, or perhaps they were simply black in a land where white privilege codes all interactions. Yes, not all police officers hate blacks, women, and other "marginalized" groups, but those who do hate seem to operate without significant challenge.

The anger felt by so many is not simply the fact that some police officers have murdered, but that these murderers by and large have gone without consequences consistent with their senseless taking of life. No charges and limited reprimand after such killings produces disillusionment and agitation for good reason. So, many look for ways to speak to this injustice, to force change to a deadly system

7 By absurdity, I mean to point to Camus's framing of the concept: the unrequited effort of humans to gain answers to the circumstances of life from a world that is non-responsive. See: (Camus 1991a, 1991b).

8 This argument is more fully developed in an early draft of my William James lecture at Harvard Divinity School, March 2017.

9 Much of this material regarding examples of racial disregard is drawn from (Pinn 2016).

10 This articulation of right "place" and "time" is sensitive to Mary Douglas's use of these concepts. For instance, according to Douglas dirt can be understood as matter out of place. See (Douglas 1996). In Body Matters, Judith Butler extends the link arguing that some marginalized groups are identified within the social system as 'shit': (Butler 2011).

11 See for examples: (Ellis and Kirkos 2017; Baker et al. 2015; Nathan 2016). 
because "Black Lives Matter". Still, the genius of white supremacy is that it mutates and transforms, and it gives up a little in order to present the illusion of fundamental change. It finds ways to blame victims for the violence perpetuated against them. There is a desperate effort to find something in the past of the victim that will justify murder as the safeguarding of order and wellbeing. At times, this something found is nothing more than the connotations blackness.

Racial violence has always been a prominent dimension of life in the United States. This is a country, truth be told, grounded and enriched through a vicious disregard for difference that allowed for the psycho-physical marginalization and brutalization of those deemed "out of place" (Douglas 1996). This is more than dynamic belittling (e.g., socio-cultural, political, and economic hostility justified through a physical marker of distinction such as race, gender, or class). Bodies are coded, and in this coding, all else is found. Social coding such as that of race is tenacious, and longstanding. Its impact is significant; it "colors"-so to speak-the outlook on life, the struggles encountered, and the range of options for resolution.

Activism toward change up to this point has been preoccupied with outcomes-measurable and permanent changes that promote wellbeing for all. Yet, while admirable in that people are putting themselves on the line, offering themselves for the sake of a larger purpose, such strategies have produced little fundamental change. There is an assumption this country can do better, that it wants to do better, that it is a good system used wrong. So, effort consistent and ongoing can make a difference. Such thinking is the basis for hope under girding ongoing protest and critique. This is not identical to, but rather draws its strength from an appeal to love. That is to say, it prompts a sense of the other that truncates the integrity of self. I would argue a prime example of this is the Christ Event embraced within the Christian tradition. This is not blaming the victim, per se, but it is a sacrifice that prompts a particularly positive depiction of suffering.

If it is love, what prevents the assumption it is the love of an abuser who damages without taking responsibility for the violence, instead preferring to believe the violence was forced by the abused? Isn't this logic found in some of the responses to the Black Lives Matter movement and other organized efforts for change? Isn't this thinking present in the vocalized assumption that protestors bring violence on themselves through their "disruptive" and divisive behavior? The idea that love is the guiding force serving to bring US citizens together is an old fallacy without historical evidence. This is theological slight-of-hand, a theologically driven wish without grounding. Where is the love in that?

I understand there is some sense of comfort-a type of space away from the chaos of life-in the claim that religion in the form of love-talk points to the answer. "If we can only get back to loving each other", so many lament in a variety of ways. This is said as if religion is a type of protective Teflon coating that has prevented hate, fear, and violence from actually penetrating the core values of the nation. And because of this coating, evil injustice is superficial and can be removed, the democratic process exercised, and life improved. ${ }^{12}$ However, such thinking fails to really consider the biblical text from which its advocates claim it is drawn. What is to be made of the violence and the divinely sanctioned destruction of life that marks the sacred texts so quickly quoted (out of context)?

\section{An Alternate Question: Life without Appeal?}

The dogma and practices of churches do little to change the "folkways, habits, customs and subconscious deeds" that contribute to the condition of African Americans (Du Bois 1970, p. 222). If anything, church dogma and theology re-enforce some of the worst patterns of thinking and hence celebrate some of the worst modes of ethics.

12 I develop this idea more fully in a variety of texts, including The End of God-Talk: An African American Humanist Theology (Pinn 2011). 
Moving back in time, there is no adequate response to the theodicy question for Du Bois; the theological wishes expressed by many, from his vantage point, fail to highlight the depth of disregard marking the historical moment and instead seek resolution either as future restitution or divine intervention in the social dynamics of belief beyond the abilities of humans. Theodical interrogations go unfulfilled; there is no response given to the question of "why, God?"13 Borrowing from Camus, I suggest, this line of questioning regarding human suffering is a mode of suicide-i.e., a surrendering of embodied integrity and agency. Instead of theodicy as a response to human suffering and misery, I prefer the question posed by the moralists: "Is life without appeal possible?" (Camus 1991a).

By this question, I aim to redirect inquiry—to push against effort to redress suffering by turning away from material life to an approach that grounds inquiry in the material, historical world. Such an arrangement urges confrontation with beliefs by pushing against comforting assumptions as one highlights and forces a view of human suffering without the affective and intellectual safeguard of theologically 'flinching' and ethically 'blinking' (Zaretsky 2013, p. 7). There is, then, no retreat from this predicament-no solace that will ultimately offer comfort (Zaretsky 2013, p. 8). For moralists, life is drowned in suffering. Questions regarding disregard, danger, and violence are met with the silence of the world (Du Bois 1995, p. 454).

$\mathrm{Du}$ Bois offers a response to theodicy, which is to reject theodicy and in its place offer philosophical-theological revolt. ${ }^{14}$ I would propose this is his turn away from theodicy toward moralism and the absurd. It, then, is intellectually akin to Camus' interrogation of the plausibility of life without appeal. Cornel West, for one, seems to measure Du Bois' sense of the absurdity of life over against his strategies and promotion of sustainable structuring of hope. However, Du Bois concerns himself with a diagnosis of the condition premised upon a cultural climate or sensibility defined by structures and strategies of disregard. Not theodicy, but rather, "how does it feel to be a problem?" (Du Bois 1986; West 1989, p. 142). By means of this question, Du Bois shifts away from the dominant narrative of religious faith marked by a certain type of fatalism-sorrow and misery until the next world or a more aggressive theology of revenge. He raises the question of pain and suffering, but as a moralist-absurdist question that rejects the fall back of a grand unity of purpose. Instead, can life be lived without appeal? In raising this question, I want to draw attention to my critique of models of theodical response to suffering that connote redemptive suffering strategies. I find such a dilemma in various modalities of constructive and liberation theologies. Here, through this question, I want to redirect theological inquiry in such a way as to jettison redemptive suffering.

Related to the above reading of Du Bois, I offer a question posed by another moralist, Richard Wright, who proclaims, "ought one to surrender to authority even if one believed that that authority was wrong? If the answer was yes, then I knew that I would always be wrong, because I could never do it. Then how could one live in a world in which one's mind and perceptions meant nothing and authority and tradition meant everything? There were no answers". (Wright 1937, p. 182). To exist is to be caught in this cultural climate. In this sense, as Susan Mizruchi notes, death and blacks "have become synonymous in white minds" (Mizruchi 1999, p. 274).

Physical death, as noted by Du Bois, and highlighted by John Wideman, is ever present; but it is not a separate reality that can be managed and bracketed off. Rather, it is akin to life, tied to life. This is only one mode of death noted by Du Bois. He also highlights another and intense mode of death, what I will call a death as metaphysical irrelevance. He writes, "you might have noted only the physical dying, the shattered frame and hacking cough; but in that soul lay deeper death than that"

13 I have made this argument in various locations, including: (Pinn 1995, 2002).

14 As my earlier work-including (Pinn 1995) demonstrates, I am aware of the various arguments made within womanist and black theological circles. I understand their nuance. However, even their effort to rethink suffering lends itself to redemptive suffering models. 
(Du Bois 1986, p. 162). This, he continues, is the "death that is more than death-the passing of a soul that has missed its duty" (Du Bois 1986, p. 162).

For instance, projection of blacks as death produced an extreme effort to control death through death. ${ }^{15}$ Kristin Hunter Lattany argues killing and death are intrinsic to the logic of the nation. Writes Lattany, "we can see that America is not a glamour queen but a grisly skeleton, her only produce death ... her only lessons how to kill and how to die". ${ }^{16}$ As I have argued elsewhere, such a take on death highlights the manner in which certain human communities are circumscribed-violently at times-so as to protect the status quo. For them, death bleeds into life and life into death. One can lament this situation and be consumed by a certain type of agony; lament this situation and struggle against it-but still maintain the dominant logic. Or, one can push against it embracing the tragic-comic nature of life. For instance, according to Black Lives Matter, like moralist Du Bois, the ever-present threat of death does not stimulate a sense of melancholy. ${ }^{17}$ Instead, death is simply a dimension of what it is to live within the context of the cultural climate in President Obama's and now President Trump's "America."18 The every present threat of death confronts all dimensions of life, and there is no relief available. This, I would argue, is the approach Job and his friends feared and his God fought against.

Circumstances-"Yes we can" and "Make America great again" narratives of national transformation—do not afford more than illusion. Following Camus, I would press the following point: "The absurd, godless world is, then, peopled with men who think clearly and have ceased to hope" (Camus 1991a, p. 92). Camus and Du Bois promote, and I advocated for over against theodicy, living into death without reconciliation but by means of comfort with vulnerability, incompleteness and awareness of the openness entailed. In a sense, the task is to confront the world and not be bent permanently and tamed by the weight of its silence.

Conflicts of Interest: The author declares no conflict of interest.

\section{References}

Baker, Al, J. David Goodman, and Benjamin Mueller. 2015. Beyond the Chokehold: The Path to Eric Garner's Death. nytimes.com, June 13. Available online: https://www.nytimes.com/2015/06/14/nyregion/ericgarner-police-chokehold-staten-island.html (accessed on 1 November 2017).

Butler, Judith. 2011. Body Matter. New York: Routledge.

Camus, Albert. 1991a. The Myth of Sisyphus and Other Essays. New York: Vintage International.

Camus, Albert. 1991b. The Rebel. New York: Vintage International.

Douglas, Mary. 1996. Impurity and Danger. New York: Routledge.

Du Bois. 1970. Dusk of Dawn. New York: Schocken, p. 222.

Du Bois, W. E. B. 1986. The Souls of Black Folk. New York: Vintage, p. 162.

Du Bois, W. E. B. 1995. W.E.B. Du Bois: A Reader. Edited by David Levering Lewis. New York: Henry Holt and Company, p. 454.

Ellis, Ralph, and Bill Kirkos. 2017. Officer Who Shot Philando Castile Found Not Guilty on All Counts. cnn.com, June 17. Available online: http:/ /www.cnn.com/2017/06/16/us/philando-castile-trial-verdict/index.html (accessed on 1 November 2017).

15 I have written about death in a variety of pieces, but the most substantial is the project I am currently completing: (Pinn forthcoming), scheduled for submission to press August 2018.

16 (Lattany 1993), I further develop this attention to death in (Pinn 2017).

17 I want to make a distinction between melancholy and nihilism. The former, I argue, involves a sense of loss-a mourning of sorts connected to circumstances lost. This isn't a rejection of life as meaningful or valuable-but rather the mourning of circumstances that reflect this meaning and value. Nihilism is the rejection of possibility. It isn't recognition of something or someone lost; rather, it is a rejection of life as having value.

18 An extension and fine tuning of this argument will be published as, "In the Wake of Obama's Hope" in (Floyd-Thomas and Pinn). 
Juan Floyd-Thomas, and Anthony B. Pinn, eds. Forthcoming; Religion in the Age of Obama. London: Bloomsbury Academic.

Lattany, Kristin Hunter. 1993. Off-Timing: Stepping to the Different Drummer. In Lure and Loathing: Essays on Race, Identity, and the Ambivalence of Assimilation. Edited by Gerald Early. New York: The Penguin Press, p. 164.

Mizruchi, Susan. 1999. "Neighbors, Strangers, Corpses: Death and Sympathy in the Early Writings of W.E.B. Du Bois". In The Souls of Black Folk: W. E. B. Du Bois. Edited by Henry L. Gates Jr. and Terri Hume Oliver. New York: W. W. Norton \& Company, p. 274.

Nathan, Debbie. 2016. What Happened to Sandra Bland? thenation.com. April 21. Available online: https: / / www.thenation.com/article/what-happened-to-sandra-bland/ (accessed on 1 November 2017).

Pinn, Anthony B. 1995. Why, Lord: Suffering and Evil in Black Theology. New York: Continuum.

Anthony B. Pinn, ed. 2002. Moral Evil and Redemptive Suffering. Gainesville: University Press of Florida.

Pinn, Anthony B. 2011. The End of God-Talk: An African American Humanist Theology. New York: Oxford University. Pinn, Anthony. 2016. On Struggle in Our Historical Moment. Huffington Post Religion Blog, July 12.

Pinn, Anthony. 2017. Presence Together: Technology of Religion and the Interplay of Things. New York: Oxford University Press.

Pinn, Anthony B., and Allen Callahan. 2007. God of Restraint: An African American Humanist Interpretation of Nimrod and the Tower of Babel. In Book African American Religious Life and the Story of Nimrod. New York: Palgrave Macmillan.

Pinn, Anthony B. Forthcoming; Cold Blooded: Hip Hop and the Cultural Grammar of Death. Durham: Duke University Press.

West, Cornel. 1982. Prophecy Deliverance! Louisville: Westminster/John Knox.

West, Cornel. 1989. The American Evasion of Philosophy: A Genealogy of Pragmatism. Madison: University of Wisconsin Press, p. 142.

Wright, Richard. 1937. Black Boy. New York: Harper and Row, p. 182.

Zaretsky, Robert. 2013. A Life Worth Living: Albert Camus and the Quest for Meaning. Cambridge: Harvard University Press, pp. 7-8.

(C) 2017 by the author. Licensee MDPI, Basel, Switzerland. This article is an open access article distributed under the terms and conditions of the Creative Commons Attribution (CC BY) license (http:/ / creativecommons.org/licenses/by/4.0/). 